Integritas 4.3 (Fall 2014), pp. 1-30.

doi: 10.6017/integritas.v4i3p1

\title{
Ending Extreme Poverty: The Call from Catholic Social Thought
}

\begin{abstract}
Amata Miller, I.H.M.
We live in a world characterized by incredible economic inequality-extreme poverty in the midst of inordinate affluence. The knowledge of how to eliminate extreme poverty exists, but the political will to do so is lacking. The tradition of Catholic social thought provides moral guidance and an ethical challenge for the development of this will through its continuity in basic principles of justice and dynamic development over time as social conditions have changed. This paper endeavors to describe the current situation, to trace the Catholic social tradition's development, and to give some examples of how education at Catholic colleges and universities can foster in its students the essential will to act for social justice through a permeation of Catholic social teaching throughout their educational experience.
\end{abstract}

Today's globalized world bombards us with news of crises of all kinds. From the perspective of this economist, rooted in Catholic social teaching, the greatest obscenity of our times is the existence of extreme poverty amid unprecedented affluence. In his Apostolic Exhortation Evangelii Gaudium, Pope Francis summarized the economic challenge of our times in one brief sentence: "Inequality is the root of social ills." Both development economists and international leaders have recognized that we currently

1 Pope Francis, Evangelii Gaudium (EG), 202, online at www.vatican.va.

Amata Miller, I.H.M., is a professor of economics, director of the Myser Initiative on Catholic Identity, and holds the Archbishop Harry Flynn Distinguished Chair in Catholic Identity at St. Catherine University. Additionally, she teaches in the Master of Arts in Social Justice Program at Marygrove College and is a member of the Global Economic Justice Workshop Team of the Partnership for Global Justice in New York City. For six years, she was the education coordinator and economic analyst at NETWORK: A National Catholic Social Justice Lobby in Washington, D.C. She has served as trustee or director of many institutions, including St. Edward's University, Marygrove College, Mercy Housing, Partners for the Common Good, NETWORK, Catholic Health Initiatives, Catholic Health Audit Network, Shorebank, and Mary's Pence. 
know how to eradicate extreme poverty but lack political will to do it. Moral leaders call people of goodwill to recognize the new moral challenge in this economic reality, one that goes beyond assistance to structural change. Through a multidimensional focus on Catholic social teaching, educators at Catholic colleges and universities can play a key role in fostering that political will in their students: increasing their sense of social responsibility, stimulating creation of institutions for the global common good, and motivating the will to address in their own spheres of influence the multifaceted reality of gross global economic injustice.

This paper will begin with a brief economic description of today's extreme global poverty and of recent progress toward its eradication. Then it will turn to the guidance on economic justice provided by the Catholic tradition of social thought, dealing with its development in different economic contexts over time, and its persistent themes. Finally it will address the opportunities for Catholic universities to permeate the educational process with the principles of Catholic social teaching in ways that foster the political will to bring about a more economically just world.

\section{The economic dimension of life is not working for many people and thus claims an inordinate amount of public attention.}

\section{Our globalized world: economic poverty amid affluence}

The economic dimension of life is meant to function like breathing, necessary to provide essentials for life, but normally doing so unnoticed. However, when one is choking or having an asthmatic attack, it claims full attention. Thus it is with the economic dimension of life today-it is not working well for many people and thus claims an inordinate amount of public attention. Coupled with this, a great deal of economic ignorance and misinformation is consistently leading to ill-informed and strongly held viewpoints. Thus, I find myself telling my graduate students, "you should have learned this in kindergarten. That you didn't is not your fault. But we will have to talk about a few basic economic principles before we can go further into our specific topic."

Pundits are calling this another "Gilded Age," a time of economic inequality between rich and poor like that of the late nineteenth century. The American Industrial Revolution was in its early stages and those called "Robber Barons" were becoming immensely wealthy. Meanwhile their workers lived in squalid tenements. Today that high degree of inequality is worldwide. Despite progress made since I990 to reduce it, extreme poverty amidst extreme affluence exists within and between countries.

In March 20I4, Forbes published its "Special Issue: The World Almanac of Wealth." Of the planet's 50 wealthiest billionaires, half were U.S. citizens, but at least one member of the group is from each of the continents except Antarctica. The richest member, Bill 
Gates, has wealth totaling \$76B; the second richest is Mexican Carlos Slim with \$72 B. ${ }^{2}$ Alongside this, the World Bank reports that I.2 billion people still live on less than \$I.25 per day (Purchasing Power Parity). ${ }^{3}$ According to the UN Development Programme, more than 2.2 billion people, fifteen percent of the world's population, are either near or living in "multidimensional poverty." Nearly twelve percent (842 million) suffer from chronic hunger. 4

Another evidence of the current inequality is that the International Monetary Fund has recently recognized the importance of using the distribution of a country's wealth and income as a criterion in determining economic success. Previously it had focused on the production side shown in sustained growth of income, inflation of prices, and a balanced budget, and neglected distribution questions, as have other agencies and scholars. ${ }^{5}$

In his massive study Capital in the 21st Century, the 500 page-plus tome briefly on the New York Times best-seller list, Thomas Piketty presented reams of historical data documenting how capitalism has produced increasing inequality in the distribution of income and wealth over the centuries. ${ }^{6}$ Market capitalism, the dominant economic system in the industrialized countries for several centuries and dominant in the world since the collapse of the Soviet Union in I990, has been the economic model for economic growth of nations since the industrial revolutions in Europe, the United States, and Japan. In the last half of the twentieth century, it was the model for economic development that the international organizations taught and facilitated in (and/or forced upon) countries emerging from colonialism and then from Soviet domination. Economic scholarship and public policy have focused on processes of economic growth in production, measured in monetary terms. Gross Domestic Product (GDP) per capita has been the basic measure. How the fruits of that growth have been distributed within and between countries has been neglected until recently. In recent years, economists and other social scientists have begun to ask whether or not economic growth has led to greater human happiness. ${ }^{7}$ The realities of the global world are exposing both the opportunities and the challenges. Environmentalists have documented the harmful effects of current capitalist models of economic growth on climate, animal life, human health, and the earth. They have drawn our attention to the sustainability of current models of economic success. Feminist scholars have shown the harmful effects of neglecting women's work in subsistence agriculture and the raising of children and maintenance of families in market-based

2 "Billionaires: The 28th Annual Guide to the World's Richest People," Vol. 193, no.4 (March 24, 2014): 32.

3

"Measuring Poverty Overview," www.worldbank.org/en/topic/measuringpoverty/overview/.

4 UN Development Programme, Human Development Report 2014: Sustaining Human Progress: Reducing Vulnerabilities and Building Resilience (New York: United Nations, 2014), 3.

5 Eduardo Porter, "In New Tack, I.M.F. Aims at Income Inequality," New York Times, April 8, 2014, sec. B, 1 .

6 Thomas Picketty, Capital in the Twenty-First Century (Cambridge, MA: Harvard University Press, 2014).

7 See for examples Richard Wilkonson and Kate Pickett, The Spirit Level: Why More Equal Societies Almost Always Do Better (London: Penguin Books, 2009). 
measures of economic growth. Market capitalism is being challenged by the rapid rise of China through an economic model including a much higher degree of government control to modify private market control. Experience in various parts of the world is raising questions about whether the current trend of increasing inequality will continue to weaken social cohesion and stimulate more civil conflict. Moral questions have been raised about the effects of the current economic system on the poor of the world by Pope Francis as well as by his recent predecessors. Though pervasive, the dominant capitalist market economic system is being questioned from many directions. This seems to be one of those teachable moments that make positive social change possible.

Economic development scholars have identified the ways that the current economic systems are generating the gap between affluence and extreme poverty. ${ }^{8}$ International advocates for economic justice have focused on the unmet needs of the poorest. ${ }^{9}$ In addition, Non-Governmental Organizations, such as OXFAM, 50 Years is Enough, and the World Fair Trade Organization have researched and worked to raise consciousness and motivate action for transformation. Key aspects of current systems are contributing to extreme poverty.

\section{The dominance of the financial sector has distorted the decision-making processes of markets in favor of the "haves" and their claims on resources to satisfy their wants.}

First, trade among nations aims to generate mutual benefits. According to the assumptions of neo-classical economic theory, free markets will do so, as individuals and groups freely pursue their own economic good. However, the reality of global markets today shows that the poorest countries, and the extremely poor within them, face markets in which their bargaining power is miniscule in comparison with that of multinational corporations and rich countries. Indeed, the "rules of the game" are stacked against them. Their trade is frequently in primary agricultural commodities whose producers are often subsidized by rich countries. This puts poor countries at a disadvantage. Furthermore, in their efforts to develop processing facilities to gain value, they face opposition from World Trade Organization (WTO) rules and conditionality in bilateral trade agreements preventing using protective tariff walls behind which to build

8 Paul Collier, The Bottom Billion: Why the Poorest Countries are Failing and What Can Be Done About It (New York: Oxford University Press, 2007); Jeffrey D. Sachs, The End of Poverty: Economic Possibilities for Our Time (New York: Penguin Group, 2005); Abhijit V. Banerjee and Esther Duflo, Poor Economics: A Radical Rethinking of the Way to Fight Global Poverty (Philadelphia: Public Affairs, 2011).

9 See an early study of effects of globalization by the International Labour Organization: World Commission on the Social Dimensions of Globalization, A Fair Globalization: Creating Opportunities for All (2004), at www.ilo.org/public/english/wcsdg/docs/report.pdf. 
their industries. ${ }^{\text {I0 }}$ History shows that countries which have successfully entered into world trade, because of favorable resource endowments or early starts, have begun the self-sustaining cycle of economic growth and rising standards of living for their people. But the extremely poor have been left behind.

Second, financial speculation and the consequent compounding of financial wealth has generated the unprecedented levels of inequality. The dominance of the financial sector has distorted the decision-making processes of markets in favor of the "haves" and their claims on resources to satisfy their wants. Economists call it "market failure" when persons or groups can control market outcomes in their favor, thus generating less than maximum social well-being. This financial dominance, operative in global markets, has deepened the inability of those in extreme poverty to access the basic necessities of life.

Third, this inability is especially evident in the inadequacy of income-producing employment and social safety nets around the world. Especially among the world's extremely poor, lack of education, health care, and even simple tools hinders access to the productive work required for meeting basic human needs as well as for the economic development of self-sustaining nations. Economists call this a "poverty trap" which, without external assistance, condemns the poorest to continual destitution.

Fourth, markets function within rules and policies set by national governments according to their cultures and priorities. Social protections for the poor and vulnerable depend on national histories, abilities, and government budgets. In recent years, governments have backed away from their regulatory and social welfare functions, and in some extremely poor countries, corrupt leadership and waste have absorbed huge portions of national economic resources at the expense of the poorest.

Fifth, because of technological development in transportation and communication, economic globalization has proceeded rapidly, and before the development of political institutions to govern situations of global interdependence. The institutions of a nationbased international order in which a few industrialized nations of the Global North are dominant cannot suffice in a global world where interdependence knows no borders. Climate change, international terrorism, and epidemics of diseases such as AIDS or Ebola testify to this vulnerability. And the poorest continue to bear the heaviest burdens from these interdependencies without enjoying the benefits available from them.

\section{Our globalized world: recent reductions in poverty}

Under the aegis of the United Nations (UN) and through the work of many since I945, many people have come to both see and understand the dimensions of the great disparity between rich and poor. By I990, the UN Development Programme began publishing annually the Human Development Index, ranking nations according to progress on proxy variables of life expectancy and education as well as GDP per capita. In 2000, the world's leaders adopted the UN Millennium Challenge in which they pledged to

10 Dani Rodrik, The Globalization Paradox: Democracy and the Future of the World Economy (New York: W.W. Norton, 2011), esp. chapter 8, "Trade Fundamentalism in the Tropics," 159-183. 
achieve eight Millennium Development Goals (MDGs) by the year 2015. Each goal had measurable targets to "improve the conditions of the poorest of the poor." were backed up by the Monterrey Consensus, at which funding commitments were made, and progress has been monitored and then documented annually in Millennium Development Goals Reports issued each July.

\section{The world reduced extreme poverty by half since 1990.}

The 20I4 Report indicated that several of the MDG targets have been met. For example, the world reduced extreme poverty by half since I 990 when almost $50 \%$ of the population of the developing countries lived on less than \$I.25 per day; it is now 22\% of the population, a decrease of 700 million people. By 20 Io the number of the world's people without access to an improved source of drinking water was half of what it had been in I990; over 2.3 billion more people had gained access. By 2012 all developing regions had achieved or were close to achieving gender parity in primary education. The target of halting deaths from malaria and reversing its incidence is likely to be met; over 3.3 million deaths from the disease were prevented between 2000 and $2012 .{ }^{12}$

The 2014 Report also pointed out that despite this progress, several of the goals' targets are unlikely to be met by the end of 20I5. Global emissions of carbon dioxide, deforestation, species extinction, and exhaustion of fresh water resources continue. Progress on reducing world hunger has slowed, leaving $14 \%$ of the population in developing regions undernourished, including I62 million young children. Preventable diseases are still the main causes of high mortality rates among children under five even though the rate decreased by almost 50\% since I990. Maternal mortality rates have dropped by $45 \%$ but 300,000 women still died in 2013 due to problems in childbirth or pregnancy. Though access to antiretroviral therapy has increased survival from AIDS, expansion of its coverage as well as further education about the disease is essential. Prevention of public health risks in poor communities requires improvement of sanitation facilities. Primary school enrollment rates in developing countries increased to $90 \%$ by 2012 and then stagnated. ${ }^{\mathrm{I}}$

The UN Conference on Sustainable Development (Rio+20) in $20 \mathrm{I} 2$ called for development of a new set of post-20I5 sustainable development goals. So the UN General Assembly established the Open Working Group (OWG) and gave them until July 20I4 to complete their task. This group concluded its I3th and final session on July I9, 20I4, when it formally adopted its proposed I7 goals with I69 targets. These are to be sent to the General Assembly to be considered along with the broader post-20I5 development

effrey Sachs, Common Wealth: Economics for a Crowded Planet (New York: Penguin Group, 2008$), 13$.

United Nations, The Millennium Development Goals Report 2014, 4-5. 
agenda scheduled to be adopted in late $2015 \cdot{ }^{\mathrm{I} 4}$

The process for developing the Sustainable Development Goals (SDGs) has been a globally participative one. Social media and the Internet facilitated global submission of input and suggested goals from diverse perspectives. Groups mobilized to assure that their particular concerns were included. Global polls were conducted online to garner and evidence support. At one point it was reported that over 1400 goals had been recommended. Final determination of the SDGs is still a work in progress.

The annual Millennium Development Goals Reports have shown that focused efforts by government, the international community, civil society, and the private sector do make progress possible when goals and targets for eradicating poverty are clearly delineated and monitored. This focus has also generated serious work by development economists as well as other social scientists on all the aspects of this complex challenge. In two books intended for non-specialists, development economists have specifically addressed this challenge. Paul Collier, an Oxford economist and former World Bank director of Development Research, shares his wisdom about eradicating extreme poverty in his prize-winning book, The Bottom Billion. He explains how the poorest billion are caught in "poverty traps" of geography, conflict, exploitation of their natural resources, and bad governance. He then indicates his recommended plan of action. ${ }^{15}$ In their more cautious approach in Poor Economics: A Radical Rethinking of the Way to Fight Global Poverty, Abhijit Banerjee and Esther Duflo lay out the complexities of eradication of extreme poverty and make the case for building the will to improve the lives of the poorest. ${ }^{16}$

The issue of eradication of extreme poverty is on the world's ongoing agenda. The MDG data shows that progress is being made. Scholars are continuing the analysis of the inherent challenges and opportunities. Philanthropists are contributing to resolution of specific issues. But the political will is still lacking. However, building that political will to raise the priority of this issue among people of developed and developing nations is essential. For that task, teaching about the Catholic tradition of social thought on economic justice can make a particular contribution.

\section{Guidance from Catholic social tradition}

The Catholic tradition of social thought is long and rich, continuous in principles and dynamic in application. Benedict XVI stressed its continuing relevance when he wrote: In today's situation, not least because of the growth of a globalized economy, the Church's social doctrine has become a set of fundamental guidelines offering approaches that are valid even beyond the confines of the Church: in the face

14 International Institute for Sustainable Development, "Summary of the Thirteenth Session of the UN General Assembly Open Working Group on Sustainable Development Goals," Earth Negotiations Bulletin Vol. 32, no. 13, July 14-19, 2014.

15 Paul Collier, The Bottom Billion. See Part 2, chapters 2-5, about the four poverty traps and Part 5 for his recommended plan of action.

16 Banerjee and Duflo, Poor Economics, 267-73. 
of ongoing development these guidelines need to be addressed in the context of dialogue with all those seriously concerned for humanity and for the world in which we live. ${ }^{\text {T7 }}$

Brian Rusche, executive director of the Minnesota Joint Religious Legislative Coalition in that state's legislature, not a Catholic himself, indicated the relevance of the tradition for all people, saying:

Catholic social teaching is the most systematic and thorough attempt by a religious faith to articulate its positions on social policy...it provides a first lens to look at nearly every social justice issue and seriously influences all our position statements. Catholic social teaching is a gift to the world and people of all faiths. ${ }^{\text {I8 }}$

Scholars differentiate among categories of this Catholic tradition: social thought, social ethics, social teaching, social gospel, and social movements. They trace different sources, different official status, different degrees of participation in their formation, different moral weight. ${ }^{19}$ Historian of the tradition David O'Brien refers to the tradition as including different understandings of what he calls "social Catholicism." ${ }_{20}$

In this paper I will use an inclusive sense of the social tradition in discussing its history and then trace the themes of economic justice found in the recognized corpus of modern Catholic social teaching in papal encyclicals since I89I and in pastoral letters of certain episcopal conferences which have addressed the topic. Particularly influential have been those of the Latin American bishops in Medellín and in Puebla, as they described the realities of destitution and oppression of their people in the spirit of what has come to be called liberation theology. In addition, the participative process used by the committee of U.S. bishops in writing their pastoral on the American economy is remarkable as an experience of the Church as people of God participating in development of the tradition in their own country.

This tradition's emphasis on the centrality of attention to the needs of the poor is rooted in the scriptural teaching on biblical justice. It is evidenced in the organization of Jewish agricultural societies described in the books of Exodus, Deuteronomy, and

17 Pope Benedict XVI, Deus Caritas Est 27.

18 Quoted in School of Social Work, "Social Work for Social Justice: Ten Principles" (St. Paul: St. Catherine University \& University of St. Thomas, 2006).

19 For fuller explanation of the differences see: Richard R. Gaillardetz, "The Ecclesiological Foundations of Modern Catholic Social Teaching," in Modern Catholic Social Teaching: Commentaries and Interpretation, ed. Kenneth Himes, O.F.M. (Washington, DC: Georgetown University Press, 2005), 86-90; John A. Coleman, S.J., "The Future of Catholic Social Thought," in Himes, 522-25; Charles E. Curran, Catholic Social Teaching: A Historical, Theological, and Ethical Analysis (Washington, DC: Georgetown University Press, 2002), 1-8.; David O'Brien, “The United States' Historical Engagement with Catholic Social Teaching," in A Vision of Justice: Engaging Catholic Social Teaching on the College Campus, eds. Susan Crawford Sullivan and Ron Pagnuccio (Collegeville, MN: Liturgical Press, 2014), 1-16. 
Leviticus, and in the exhortations of the prophets Isaiah and Amos. For example, in the story of the burning bush, Moses is sent to tell the people that God has heard their complaints and will liberate them from their slavery in Egypt. ${ }^{2 \mathrm{I}}$ This Exodus theme of liberation of the poor and vulnerable continues as a sign of the kind of work that is pleasing to God. ${ }^{22}$

Scripture presented the Jubilee principle as an institutionalized way to prevent extreme inequalities. Though we do not have historical evidence about its implementation, Jubilee called for the return of all land to its original owners without compensation every 50 years. Economic equality was to be restored since access to land, the basic means of producing wealth in an agrarian society, was seen as God's way of providing for basic human sustenance. ${ }^{23}$

Jewish law also provided for the sabbatical year of liberation of soil, slaves, and debtors every seven years as an institutionalized way of attending to the needs of society's poorest. For both ecological and humanitarian reasons, the land was to lie fallow. Slaves were to be set free and given a share in what their labor had produced. All debts were to be cancelled every seven years and it was forbidden to refuse a loan to a poor person in the sixth year. Historians have found data that this law was observed at least at some periods. ${ }^{24}$

Laws of tithing and gleaning were another institutionalized way of preventing extreme economic inequalities. One-tenth of all farm produce was to be set aside as tithe for the Levites and the poor, especially fatherless children, widows, and "sojourners in the land." ${ }^{25}$ Also, farmers were required to leave some of the harvest, including the corners of grain fields and grapes dropped accidentally, so the poor would have a means to avoid debilitating poverty. ${ }^{26}$ These established social structures provided for the most vulnerable while allowing them to maintain their personal dignity.

In addition, in Jewish society there were prohibitions against charging interest on loans. In antiquity, most loans were charitable, made in cases of personal emergency, not commercial transactions. The laws were intended for protection of the poor and as a way to prevent extreme economic inequality between rich and poor. ${ }^{27}$ This prohibition has a long history in Christian tradition, since the Third Lateran Council in II79 forbade all interest on loans, and this prescription of canon law lasted until $19 \mathrm{I} 7^{28}$

21 Ex 3:7-10.

22 Ex 22:20-22; Is 58:6-7.

23 Lv 25:8-17; Ronald J. Sider, Rich Christians in an Age of Hunger: A Biblical Study (New York: Paulist Press, 1977), 88-90.

24 Ex 23:10-11; Dt 15:1-6, 12-18; Sider, 90-92.

25 Dt 14:28-29; Lv 27:30-32; Sider, 92.

26 Lv 19:9-10; Dt 24:19-22; Sider, 92-93.

27 Ex 22:25; Sider, 94.

28 Sider, 94-95; Amata Miller, "Once a Sin, Now Good Stewardship," in Rome Has Spoken: A Guide to Forgotten Papal Statements, and How They Have Changed Through the Centuries, eds. Maureen Fiedler and Linda Rabben (New York: Crossroad Publishing Company, 1998), 202-6. 


\section{By beginning his public ministry with the announcement \\ that he was sent to bring glad tidings to the poor, Jesus reiterated the Hebrew Testament's theme of the centrality of economic justice for all.}

By beginning his public ministry with the announcement that he was sent to bring glad tidings to the poor, Jesus reiterated the Hebrew Testament's theme of the centrality of economic justice for all. ${ }^{29} \mathrm{He}$ and his closest disciples lived the economy of a common purse, sharing financial resources, a life of unlimited liability for one another, and unselfish sharing. ${ }^{\circ}$ His parables reminded his listeners about God-intended priorities: that one cannot serve both God and money, one cannot put economic security in having. ${ }^{3 \mathrm{I}}$ And in the stories of Dives and Lazarus and of the Good Samaritan, he showed selfless attention to the material needs of the poor and vulnerable as ultimate witness to love of God. ${ }^{2}$

The early followers of Christ lived lives of "unlimited economic liability for and total economic availability to" the other members of the religious community. ${ }^{33}$ They held all in common, but retained their private properties, selling them as needed to meet the needs of others. Testimony from the third and fourth centuries shows that the Christians cared for the needy of both their own community and others. ${ }^{34}$ For them the economic dimension of life meant priority for the poorest. The oft-quoted words from St. Basil capture their spirit: "That coat hanging in your closet, unused, does not belong to you. It belongs to the poor person in need." Other early saints made clear that riches are intended for sharing with others. ${ }^{35}$

What we call the Middle Ages, roughly from the disintegration of the Roman Empire to the Renaissance, was economically dominated by the system of feudalism, a manorial organization of society. During this time, custom established the social hierarchy and Christian religious ideals shaped economic life. Spiritual or temporal feudal lords ruled swaths of territory centered around a manor surrounded by a protective moat and acres of land tilled by his serfs. These serfs were assigned to a certain plot of land to cultivate, and obliged to provide certain services and portion of their crop to the lord and certain

29 Lk 4:18.

$30 \operatorname{In} 12: 6$.

31 Mt 6:24; Lk 12:16-21. See the insightful treatment of "Mammon illness" in John C. Haughey, S.J., The Holy Use of Money: Personal Finances in Light of Christian Faith (Garden City, NY: Doubleday, 1986), $10-17$.

32 Lk 16:19-31, 10:25-37.

33 Sider, 101.

34 Sider, 108-9.

35 Pontifical Council for Justice and Peace, Compendium of the Social Doctrine of the Church (Washington, DC: USCCB Publishing, 2004), 329. 
money payments or dues for use of the lord's mills or ovens. In return they received physical security and assistance in time of famine, and were entitled to use the lord's tools and animals for cultivating his piece of land (although paying for this). Thus mutual support was provided in an era when famines, plagues, and dangers from marauders were common. Money-making was viewed with suspicion. ${ }^{36}$ Inequality was not the issue of this period in which subsistence was the common concern and egalitarianism and customs of hospitality and sharing were social values.

In succeeding centuries, Renaissance and Enlightenment movements brought dramatic social, political, and economic changes to Western societies. Growing calls for freedom and democracy spawned the French Revolution. Political realignments gave birth to nation states and diminished Vatican power. New Christian sects were born and reform within the Catholic Church ensued. Gradually, monetization, commercial expansion, development of market capitalism, technological innovations, and industrialization generated the modern economic dimension of human life.

Numerous social scientists and historians have documented this complex economic history, intertwined as it has been with cultural, social, political, and aesthetic trends. Historians of Catholic social tradition have rooted it in the biblical tradition and concentrated on modern Catholic social thought beginning with Pope Leo XIII's I89I encyclical Rerum Novarum. ${ }^{37}$ However, theologian Michael Schuck dates the beginning of modern social thought to the period beginning I740. Seeing views of the time as transcending usual labels of "liberal," "conservative," and "radical," Schuck categorizes the social thought and action of leading Catholics, laity and clerics, as traditionalist, cosmopolitan, or transformational. $3^{8}$

Traditional Catholics were those who longed for a return to the social and political arrangements of the Middle Ages, a viewpoint capsulized in the words "throne and altar." Cosmopolitans were favorable to greater freedom, especially when it meant an improvement in living conditions. Transformationalists had a longer-term vision of structural change to foster greater equity. ${ }^{39}$ The period of I740-I890 saw prolific growth in social thought and action. Multiple congregations of women religious were founded and began orphanages, schools, and hospitals to meet the needs of the poor. ${ }^{\circ}$ Pauline Jaricot founded the Propagation of the Faith and established an early worker-owned

36 Robert L. Heilbroner, The Making of Economic Society (Englewood Cliffs, N): Prentice Hall, 1962), 2941. See this section for a masterful summary of economic structure in this period of Western history.

37 See for example Charles E. Curran, Catholic Social Teaching: A Historical, Theological and Ethical Analysis (Washington, DC: Georgetown University Press, 2002); Donal Dorr, Option for the Poor: A Hundred Years of Catholic Social Teaching (Maryknoll, NY: Orbis Books, 1992).

38 Michael Schuck, "Early Modern Roman Catholic Social Thought, 1740-1890," in Kenneth Himes, O.F.M., ed. Modern Catholic Social Teaching: Commentaries and Interpretations (Washington, DC: Georgetown University Press, 2005), 99-124.

39 Schuck, 101.

40 Schuck, 108, 116. 
factory and equitable community. ${ }^{4 \mathrm{I}}$ Frederic Ozanam founded the Society of Vincent de Paul not only to serve the poor but also to bring the non-poor across class boundaries to contact them..$^{42}$ The Jesuits established indigenous communities in Latin America to enable communities to move beyond subsistence. ${ }^{43}$ Though Pius IX's condemnation of modernity in his Syllabus of Errors has come to summarize Catholic thought in the pre-I89I period, the social tradition was developing through the work and lives of many of those living through and grappling with the complexity of multifaceted and drastic change all around them.

\section{Education about the key principles of Catholic social teaching in Catholic colleges and universities can help build the political will to bring about a more just and humane economy for all people.}

\section{Modern Catholic social teaching: economic justice}

Popes and scholars debate the use of the terms social teaching, social doctrine, social thought. ${ }^{44}$ In the previous sections of this paper, the broader sense was used to describe the foundational principles. At this point the emphasis will be on the official expression of these teachings since I89I in papal encyclicals, episcopal pastoral letters, and documents of the Second Vatican Council. The intent of this teaching is twofold: to guide conscience formation of Catholics and to insert the moral dimension into public discussion of social issues. 45 This paper focuses on the eradication of extreme economic poverty generated by current economic systems, so it will deal with key economic justice themes, continuous over time and relevant to economic justice today. (Parenthetically, though he has not yet written a social encyclical, Pope Francis's strong words thus far about current economic reality clearly build on the themes of his predecessors as well as on his own experience.) After the review of Catholic Social Teaching (CST), this paper hopes to show how education about the key principles of Catholic social teaching in Catholic colleges and universities can help build the political will to bring about a more just and humane economy for all people.

In light of the two purposes of CST, the I986 pastoral letter of the American bishops, Economic Justice for All: Pastoral Letter on Catholic Social Teaching and the U.S. Economy (EJA) has particular significance. It focuses specifically on economic justice, its biblical

41 Schuck, 191, 114.

42 Schuck, 108

43 Schuck, 104-5.

44 Himes, Modern Catholic Social Teaching, 3-4.

45 U.S. Conference of Catholic Bishops, Economic Justice for All: Pastoral Letter on Catholic Social Teaching and the U.S. Economy (1986), 27, online at www.usccb.org/upload/economic_justice_for_all.pdf. 
roots, and expression of the principles in modern Catholic social teaching. It has particular relevance for students in our colleges and universities since it applies those principles to the American economic experience. According to noted social ethicist David Hollenbach, S.J.,

the challenge of EJA today is somewhat different than it was when the bishops issued their letter twenty-five years ago. But this challenge remains as demanding and controversial today as it was when the document first appeared. ${ }^{46}$

The demands of economic justice as well as the continuing controversy about them deserve the attention of Catholic educators. The eloquent words of EJA, summarizing scriptural and papal teaching about economic justice, serve us well for this task. Hence they will be cited frequently in this paper's summary of modern CST as we attend to Io particularly pertinent themes as they relate to economic justice for the poorest.

First, addressing the purpose of all economic systems, the bishops began the first chapter of their pastoral letter with the seminal point that the focus is on people:

Every perspective on economic life that is human, moral and Christian must be shaped by three questions: What does the economy do for people? What does it do to people? And how do people participate in it? ${ }^{47}$

This purpose corresponds with descriptions of the purpose of the economic system in basic economics textbooks: maximizing social well-being. The economy should provide what is necessary for the flourishing of human life. As a social science, economics focuses on both efficiency and equity, though media emphases continue to shape the mistaken public impression that an economic system is only about making more and more money.

Second, the dignity of every person is the foundational principle of CST on which all the other principles are based. Leo XIII's words in the beginning of Rerum Novarum $(\mathrm{RN})$ are timely for us, over a century later:

It is no easy matter to define the relative rights and mutual duties of the rich and of the poor, of capital and of labor. And the danger lies in this, that crafty agitators are intent on making use of these differences of opinion to pervert men's judgments and to stir up the people to revolt. In any case we clearly see, and on this there is general agreement, that some opportune remedy must be found quickly for the misery and wretchedness pressing so unjustly on the majority of the working class. $4^{8}$

Leo's era saw heated debates about capitalism and socialism, and they recur today in questions about whether Pope Francis is a Marxist. Polarization and ideological rigidities dominate media presentations of economic issues and foster widespread

46 David Hollenbach, S.J., "Economic Justice and the New Challenges of Globalization," in The Almighty and the Dollar: Reflections on Economic Justice for All, ed. Mark J. Allman (Winona, MN: Anselm Academic, 2012), 113.

47 EJA 1.

48 Pope Leo XIII, Enclyclical Rerum Novarum (1891), 2-3. 
political dysfunction. Emphasis on the fundamental principle of the dignity of each person is especially critical for giving priority to eradicating extreme poverty. It is the first principle in all lists of Catholic social teaching as well as in the United Nations Universal Declaration of Human Rights (UDHR). A particularly powerful statement of this principle is found in Economic Justice for All.

At the summit of creation stands the creation of man and woman, made in

God's image. As such, every human being possesses an inalienable dignity that stamps human existence prior to any division into races of nations and prior to human labor and human achievement.49

John XXIII's Pacem in Terris (PT) outlines the rights of every person to those things necessary to sustain life. He names these as "particularly food, clothing, shelter, medical care, rest, and, finally, the necessary social services" and goes on to name "the right to be looked after in the event of ill-health; disability stemming from his work; widowhood; old age; enforced unemployment; or whenever through no fault of his own he is deprived of the means of livelihood." 50 The denial of these to those in extreme poverty is thus a form of denial of the fundamental right to life. Pope John's delineation of these rights in I963 was hailed by the human rights community as a renewal of the spirit of the Universal Declaration of Human rights. Given the reality of extreme poverty amid inordinate affluence today, it is important to incorporate this understanding into the narrower "right to life" perspective of our time.

Third, CST is clear that human beings are inherently social; we are born into our families and live in social communities of various sizes. As time has gone on, human understanding of the societies to which we belong and for which we have responsibility has widened. In the I930s, Pius XI called for preservation of the national common good, echoing Leo XIII ${ }^{\mathrm{I}}$ in assigning a responsibility to governments to promote that good for all. He called for special attention to the "infirm and needy." ${ }^{2}$ He also spoke about the distribution of the fruits of economic progress.

Therefore, the riches that economic-social development constantly increase ought to be so distributed among individual persons and classes that the common advantage of all, which Leo XIII had praised, will be safeguarded; in other words, that the common good of all society will be kept inviolate. By this law of social justice, one class is forbidden to exclude the other from sharing in the benefits. ${ }^{33}$

By the I960s, John XXIII called for a realization of the need to safeguard the universal common good, and of the necessity for some kind of public authority which can operate effectively to do so.

49 EJA 32.

50 Pope John XXIII, Pacem in Terris (1963), 11.

51 RN 26.

52 Pope Pius XI, Quadragesimo Anno (1931), 25.

53

QA 57. 
Today the universal common good presents us with problems which are worldwide in their dimensions; problems, therefore, which cannot be solved except by a public authority with power, organization and means co-extensive with these problems, and with a world-wide sphere of activity. Consequently the moral order itself demands the establishment of some such general form of public authority. ${ }^{54}$

Motivating for a political will to eradicate extreme poverty calls for a commitment to the universal common good and an understanding of its implications for a new sense of national sovereignty. New institutions have to be created for this new era of global interdependence.

Fourth, John XXIII spoke of the need for a spirit of solidarity among all in the human family to undergird these worldwide political structures, ensuring that they respect individuals and cultures in their pursuit of the universal common good. ${ }^{55}$ Two decades later, John Paul II defined solidarity eloquently as a virtue called for by the reality of human interdependence:

This then is not a feeling of vague compassion or shallow distress at the misfortunes of so many people, both near and far. On the contrary, it is a firm and persevering determination to commit oneself to the common good; that is to say to the good of all and of each individual, because we are all really responsible for all..$^{6}$

Defining the active significance of this virtue, John Paul II called for transformation of perspective and conversion of heart resonant of the Gospel message of agapic love:

Solidarity helps us to see the "other"-whether a person, people, or nation-not just as some kind of instrument, with a work capacity and physical strength to be exploited at low cost and then discarded when no longer useful, but as our "neighbor," a "helper" (cf. Gen. 2:18-20), to be made a sharer, on a par with ourselves, in the banquet of life to which all are equally invited by God.57

Benedict XVI expanded on his predecessor's teaching, calling for new economic understandings that will open up the opportunities of globalization so as to "promote a person-based and community-oriented cultural process of worldwide integration that is open to transcendence. ${ }^{58}$ In his encyclical for the fortieth anniversary of Paul VI's Populorum Progressio (PP) about the authentic development of peoples, Benedict advocated a new kind of economic order in which the economy is seen as a multilayered phenomenon in which civil society, the market, and government have roles. He reiterated the sense of solidarity as "a sense of responsibility on the part of everyone

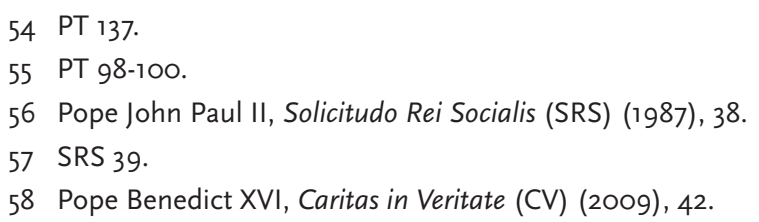


with regard to everyone" 59 which, therefore, cannot just be relegated to governments. Solidarity is the key spirit necessary to develop the political will to do what is necessary to eradicate extreme poverty.

Fifth, another relevant theme in Catholic social teaching is the universal purpose of material things. The right to private property is affirmed throughout documents, and always joined to this affirmation is the inherently related responsibility to attend to the basic human needs of others. ${ }^{60}$ Paul VI said it clearly:

That is, private property does not constitute for anyone an absolute and unconditioned right. No one is justified in keeping for his exclusive use what he does not need, when others lack necessities. ${ }^{6 \text { I }}$

John Paul II reiterated that private property is under a "social mortgage" which, he wrote, means "it has an intrinsically social function, based upon and justified precisely by the principle of the universal destination of goods." ${ }_{2}$ This principle also grounds the responsibility for care of the earth and just distribution of its abundant fruits. This principle is not as well known as other components of CST, but recognition of the social responsibility inherent in private ownership is especially critical in nurturing a political will to give priority to the needs of the world's extremely poor today.

Sixth, one of the more well-known components of the tradition of Catholic social thought is what has become known as the "preferential option for the poor." ${ }_{3}$ As indicated above, this principle is deeply rooted in the Jewish scriptural tradition and the Christian gospel. But in modern CST, there are special developments in its meaning and moral significance given the changes over time in the human situation and in our understandings of ourselves and of our interdependence. Obviously, the scope of this principle's applicability has become global as modern means of communication have made us aware of the needs of the whole human family and the gross inequalities between rich and poor nations and within them. Additionally, John Paul II and social ethicists like David Hollenbach, S.J., have made us aware of moral priorities. They have stressed that some moral goods take priority over others; there are "claims in conflict" to be considered. ${ }^{64}$ In a summary statement, John Paul said:

The needs of the poor take priority over the desires of the rich; the rights of workers over the maximization of profits; the preservation of the environment over uncontrolled industrial expansion; production to meet social needs over production for military purposes. ${ }^{65}$

$59 \mathrm{CV}_{3} 8$.

60 RN 4-6; QA 45-46; MM 119; PT 22; CS 69, 71; PP 23; CA 30-43; EJA 114-15. Compendium, 328-29.

61 Pope Paul VI, Populorum Progressio (PP) (1967), 23.

62 SRS 42. This "social mortgage" is also described in EJA 115 and in EG 189.

63 Pope Paul VI, Octagesima Adveniens (OA) (1971), 23; SRS 42; PP 47-49; EJA 24, 87.

64 See David Hollenbach, S.J., Claims in Conflict: Retrieving and Renewing the Catholic Human Rights Tradition (New York: Paulist Press, 1979), 150-52.

65 EJA 720. This is a quotation from John Paul II's 1984 visit to Canada. 
This kind of moral reasoning, in which one considers a hierarchy of moral goods, not only good vs. evil, has become necessary in making mature moral judgments about economic justice today. This kind of reordering of priorities is critical for developing the political will for eradication of extreme poverty.

Seventh, our tradition reminds us of the threefold definition of justice delineating the types or modes of justice described in the documents of CST. ${ }^{66}$ The most common understanding of justice is "fairness" as experienced in exchange between individuals and private groups. But this is only one kind of justice, commutative, which cannot exist without the other two kinds of justice in society, distributive and social justice.

Distributive justice "requires that the allocation of income, wealth and power in society be evaluated in light of its effects on persons whose basic material needs are unmet" ${ }^{67}$ and it "will be realized when social patterns are so organized that they meet the minimum needs of all persons and permit all an equal opportunity to participate in the public activities which meet these needs." 68 Social justice, also called "contributive," means that "persons have an obligation to be active and productive participants in the life of society and that society has a duty to enable them to participate in this way." 69 Pius XI said that social justice is the spirit that should pervade the ordering of all economic and social activity..$^{70}$ Internalizing and embodying this trifold understanding of justice is especially important for those socialized to the individualism so characteristic of United States' culture yet living in a globally interdependent world.

Eighth, connected to this broader understanding of justice is the recognition of sinful social structures. In his I980 encyclical, John Paul II pointed to the major world problem of the "continuing chasm in living standards" between the industrialized world and the developing world and the inadequacies of the current socio-economic-political structures to address it:

So widespread is the phenomenon that it brings into question the financial, monetary, production and commercial mechanisms that, resting on various political pressures, support the world economy. These are proving incapable either of remedying the unjust social situations inherited from the past or of dealing with the urgent challenges and ethical demands of the present. ${ }^{7 \mathrm{I}}$

He later expanded on this strong denunciation in his fuller treatment of how social structures could rightly be called sinful. This is because they are ultimately rooted in sins of individuals and then are institutionalized and spread as others are socialized within these structures. Such sinful structures, he says, absolutize human attitudes of

66 See the extended treatment of these three types of justice in Hollenbach, Claims in Conflict, 145-56, and in EJA, 68-76.

67 EJA 70.

68 Hollenbach, Claims in Conflict, 151.

69 EJA 71.

70 QA 88.

$71 \mathrm{RH} 16$. 
"all-consuming desire for profit" and "thirst for power with the intention of imposing one's will upon others." Urging application of moral criteria in evaluating current social structures, he adds:

If certain forms of modern 'imperialism' were considered in the light of these moral criteria, we would see that hidden behind certain decisions, apparently inspired only by economics or politics, are real forms of idolatry: of money, ideology, class, technology. ${ }^{2}$

This points to the depth of moral conversion, both individual and structural, required for development of the political will to address the "chasms" that have grown only wider over recent decades. It also emphasizes that social justice must inevitably go beyond assistance to the poor to transformation of social structures to eradicate extreme poverty.

Pope Francis made this point emphatically in his 2013 Apostolic Exhortation:

As long as the problems of the poor are not radically resolved by rejecting the absolute autonomy of markets and financial speculation and by attacking the structural cause of inequality, no solution will be found for the world's problems, or for that matter, to any problems.73

Ninth, as well as stressing government's responsibility to assure the common good, CST emphasizes the importance of subsidiarity in social arrangements of all kinds. Pius $\mathrm{XI}$ gave the basic definition to describe appropriate delineation of social structures:

As history abundantly proves, it is true that on account of changed conditions many things which were done by small associations in former times cannot be done now save by large associations. Still, that most weighty principle, which cannot be set aside or changed, remains fixed and unshaken in social philosophy: Just as it is gravely wrong to take from individuals what they can accomplish by their own initiative and industry and give it to the community, so also it is an injustice and at the same time a grave evil and disturbance of right order to assign to a greater and higher association what lesser and subordinate organizations can do. For every social activity ought of its very nature to furnish help to the members of the body social, and never destroy and absorb them. ${ }^{74}$

The implementation of this principle, the degree of subsidiarity required for various economic and social functions, spurs many of the debates about the size of government and the ability of markets to generate social justice today.75

In his 2009 encyclical, Benedict XVI drew out the importance of both solidarity and subsidiarity together to assure economic and humane processes in social structures of all kinds. He praised the development of a third sector, business organizations devoted to social welfare rather than to profit, to counter the dominance and power of huge

72 SRS $36-37$.

73 EG 202.

74 QA 79.

75 See Michael Novak's writings, such as The Catholic Ethic and the Spirit of Capitalism (New York: Free Press, 1993). 
corporations and of governments in today's societies..$^{6}$ Social entrepreneurship is taking many new forms today and is a sign of response of the business sector to the economic challenges of inequality, extreme poverty, and ecological devastation.

Tenth, a final key theme of CST is that of the responsibility of all Christians to act for justice. The vision of the Church as people of God involved in the world was clearly laid out in the opening words of the Second Vatican Council's Pastoral Constitution:

The joys and the hopes, the griefs and the anxieties of the men [sic] of this age, especially those who are poor or in any way afflicted, these too are the joys and hopes, the grief and anxieties of the followers of Christ. Indeed, nothing genuinely human fails to raise an echo in their hearts. ${ }^{77}$

In the synod document following the Council, the bishops dealt with implementation of its teachings. In their name, Paul VI issued Justice in the World, which clearly stated the importance of action for justice:

Action on behalf of justice and participation in the transformation of the world fully appear to us as a constitutive dimension of the preaching of the Gospel, or in other words, of the Church's mission for the redemption of the human race and its liberation from every oppressive situation..$^{78}$

\section{Church teaching is clear that action for justice is a "constitutive dimension" along with participation in Eucharist and prayer, all rooted in the same fundamental love of God.}

Sadly, current polarization exists among Catholics as to whether action for justice is really part of being a Catholic or only a voluntary activity of those who are "do-gooders" and "social activists." For some, action for justice is not seen as truly a part of the faith as being at perpetual adoration. This polarization absorbs energy urgently needed to address the economic injustices before us. Church teaching is clear that action for justice is a "constitutive dimension" along with participation in Eucharist and prayer, all rooted in the same fundamental love of God, expressed in love of one's sisters and brothers.79 Education about the social dimensions of discipleship, about what action for justice means in a globalized world, is critical to developing that "constituency of conscience" that judges all social realities by how they affect "the least, the lost, and the

$76 \mathrm{CV}_{4} 6,57-58$

77 GS 1.

781971 Synod of Bishops, Justitia in Mundo (JM), Introduction, online at www.shc.edu/theolibrary/ resources/synodjw.htm.

79 See Thomas I. Schubeck, Love That Does Justice (Maryknoll, NY: Orbis Books, 2007) for full treatment of this theme. 
left-out among us," and acts accordingly. ${ }^{80}$ Thus, educators in Catholic universities have a key opportunity and challenge to develop the understandings and the will for action for justice and transformation of the world.

This brief summary of key economic justice themes from modern CST points to some of the principles that can shape a faith-based perspective to motivate in our students the political will to be agents of transformation, people who work in their own spheres of influence throughout their lives, for a world in which extreme poverty is eradicated. What does this mean for us?

\section{Challenges and opportunities for Catholic higher education}

Viewed through the lens of Catholic social teaching, the realities of extreme poverty amidst unprecedented abundance bring some urgent challenges for Catholic higher education. How can we help our students develop the political will to eradicate extreme poverty? How can we help them become, within their own spheres of influence, agents of the kinds of social, political, and economic change that are necessary to accomplish it? A few suggestions may be useful.

\section{We have generations of students who are not only ignorant about the economic dimension of reality, but worse, are prey to errant myths and rigid ideologies that distort their views of individual and social life.}

In various words in the mission statements of our universities we promise our students an education to wholeness, exposure to the many ways of knowing through study of the liberal arts, rooted in the Catholic intellectual tradition. ${ }^{8}{ }^{8}$ However, education about the economic dimension of life is often ignored. It is often considered to be, and/ or taught as, only a business-related area of concern. Its inherent connections to all the other dimensions of life are obscured by the structures as well as the curricula of our universities. Thus we have generations of students who are not only ignorant about the economic dimension of reality, but worse, are prey to errant myths and rigid ideologies that distort their views of individual and social life. Thus, it is incumbent on us to foster curricula and interdisciplinary experiences that include understanding of the experience of the "real world," of the poor and marginalized, as well as the interdependence of the economic aspects of life with all of the other aspects. ${ }^{82}$ Otherwise, we are complicit in giving the economic dimension of life a false dominance which allows for simply

80 EJA Introduction, 27.

81 See John C. Haughey, S.J., Where is Knowing Going? The Horizons of the Knowing Subject (Washington, DC: Georgetown University Press, 2009). Chs. 5,6,7 in particular deal with the Catholic intellectual tradition. 
accepting its inequities and exclusions as inevitable.

As part of our mission we also promise that our universities will help our students mature ethically. In our individualistic American culture, this is too often seen as purely personal. Yes, we want our graduates to be honest, loyal, and loving individuals. But our Christian tradition calls us to educate our students to social responsibility, to a political will that understands the meaning of distributive justice and the inherent call to action to bring about a more just and humane world for all of our brothers and sisters, in a spirit of solidarity as well as freedom. Thus, making sure that Catholic social teaching is no longer the best kept secret of the Church is part of our responsibility.

For those students who come to us familiar with the social teaching of the Church, their university education should deepen their understanding of, respect for, and appreciation of the Church's social tradition. For those who come to us uninformed about it, we should have places in the general education core where the principles are taught. At St. Catherine University, for example, the principles are an integral part of the two courses required of every undergraduate: “The Reflective Woman," taken in the first year, and "Global Search for Justice" as the capstone. Education about the Universal Declaration of Human Rights (UDHR) and the social teachings from other religious and philosophical traditions along with CST demonstrates the universal applicability of the principles of social responsibility. Without both individually and socially ethical populations, the political will to make the public policy decisions necessary to eradicate extreme poverty will never be attained.

Developing a deep sense of social responsibility among our students, pluralistic in every way, is an expression of our Catholic identity, our sense of the mission to spread God's kingdom. In Jesuit Walter Ong's metaphor, that means being like yeast in society, within one's own sphere of influence. The metaphor of yeast signifies transforming the whole without converting it into something other than itself. ${ }^{8}$ It means teaching about how to be socially just without proselytizing. It calls for interaction and interpenetration, bringing faith-based values into contact with understandings from other disciplines. This paper's brief overview of the Catholic social teaching tradition aimed to show the integral relationship between Catholic identity and the understanding of, and critical thinking about, the moral dimensions of current economic realities. Developing habits of thought which naturally bring these faith-based dimensions into pluralistic dialogues about current economic issues is critical to generating the political will for action.

A pedagogical model for developing such a habit of mind has a long history in the development of Catholic social thought. The "see/judge/act" model of Belgian Cardinal Joseph Cardijn inspired early twentieth century social action among groups such as Young Christian Students and the Christian Family Movement. ${ }^{84}$ And this model is also rooted in the educational insights Paulo Freire expressed in his Pedagogy of the

83 Walter Ong, S.J., "Yeast," America, April 7, 1990, 348.

84 Joe Holland and Peter Henriot, S.J., Social Analysis: Linking Faith and Justice, Revised and Enlarged ed. (Maryknoll, NY: Orbis Books, 1983), 10. 
Oppressed, which focused on the links between raising consciousness about oppression, dialog among all involved in unjust situations, and motivation of all to action for social transformation. ${ }^{85}$ Thus, this model is called "the pastoral circle," the "circle of praxis," the "hermeneutic circle," or "Moving toward Social Justice" (as we've named it at St. Catherine University). It is composed of four key elements that form a habit of thought, a way of thinking, that unites understanding of a social situation of injustice and moral principles into plans for transformational action. These are:

1. Reflection on the Experience of Injustice: either through physical interaction with those experiencing the unjust situation (such as immersion trips), or virtually through videos, film, or other media that convey the experience.

2. Social Analysis: learning about the situation by consulting the best data and scholarship in order to diagnose the structural causes of the injustice, using questions based on a transformational perspective-such as, Who gains and who loses? Who has the power and how did they get it? What cultural realities are operative? What role is religion playing in this? etc., in order to understand the cause and also the alternative options for effective action for change.

3. Moral Judgment/Theological Reflection: applying moral principles from CST, the UDHR, and/or one's own traditions to the new understandings of effective options in order to judge among them about what are the moral values involved.

4. Action Planning: coming to individual or group sense of what to do about the injustice at this stage, given the realities of the situation and all the available resources. ${ }^{86}$

This is an open cycle, not a closed circle, since once action has been taken, one faces a new situation, and the work of justice goes on. As a way of thinking, this model moves one habitually from the personal to the social, the individual to the structural, the anecdotal to the analytical, the local to the global, and ultimately from a sense of guilt to one of co-responsibility. Helping students to form this habit of thought will develop the political will, individual by individual, to address the issues from the perspective of their moral priority.

Assignments in any course can be used to strengthen understanding of the meaning of the principles of CST by requiring use of moral judgment in dealing with justice issues inherent in the course content.

For example, in courses in professional fields, the codes of ethics of the profession can be linked to the relevant principles of CST. At St. Catherine University, faculty in

85 Holland and Henriot, 8; Paulo Freire, Pedagogy of the Oppressed (New York: Seabury Press, 1970). Freire's seminal theory of how developing self-awareness among both the oppressed and the oppressors can lead to liberating social action is laid out in four brief chapters.

86 Fuller explanations of the elements of this cycle can be found in: Holland and Henriot, Social Analysis, 8-10, 95-105; Thomas Massaro, S.J., Living Justice: Catholic Social Teaching in Action, 2d Classroom Edition (Lanham, MD: Rowman \& Littlefield Publishers, 2012), 71-75; Rita Hofbauer, G.N.S.H., Dorothy Kinsella, O.S.F., and Amata Miller, I.H.M., Making Social Analysis Useful (Washington, DC: Leadership Conference of Women Religious, 1985), 1-35. 
social work, nursing, occupational therapy, and physical therapy have worked to identify which principles tie to their specific codes, and have made a grid with the words from the code and from Catholic social teaching in different print fonts to identify them. These grids are used in courses throughout the majors, with various courses covering different principles. In the Business Administration department, courses in management and in accounting use case studies. Faculty have developed a tool called the "Ethical Evaluator" based on CST principles for assessing and discussing those cases. This tool has been presented at several national business education conferences and received enthusiastic reviews from peers as well as from the students. Along with the emphasis in the two core courses taken by every undergraduate student, these are ways that principles of CST are made a continual part of a St. Catherine education, and thus, contribute to building a sense of global solidarity and co-responsibility for the common good.

Co-curricular activities can also play an important part in shaping a perspective of social responsibility for transformational leadership. Building community engagement experiences combined with reflection and critical analysis into classes is a way to build solidarity and cross cultural understandings. ${ }^{87}$ Preparation for these experiences can include discussion of the importance of going beyond a sense of service to one of mutual enrichment in learning from another's experience, and the importance of co-responsibility for the common good. In addition, the disciplinary procedures for students living in residence halls can be rooted in the sense of the inalienable dignity of every person, the importance of solidarity in community, and working for the common good. Then infractions can be used as occasions to work with students about the reason for the policies and the principles on which they are based. Rather than simply imposing sanctions, this positive, restorative justice approach can help build the sense of co-responsibility for social outcomes. Also, immersion trips, both global and intranational, can widen perspectives and deepen critical analysis of social, economic, and political structures which cause harmful inequities and injustices. ${ }^{88}$ Building wellplanned and interactive reflection processes to ponder the social moral implications of all of these experiences can enhance the transformational as well as the personal perspective of the participants.

Because of the diversity of backgrounds and belief systems of faculty and staff of our universities today, it is important to give priority to education for understanding of, respect for, and appreciation of Catholic beliefs, and in particular (in the context of this paper), in CST. If our education is to help build among our students the morality to undergird the political will for global social responsibility, it is clearly not just the work of theologians and campus ministers. It has to permeate the mindset of the faculty and staff. Orientations of new faculty and staff have to include explicit introductions to what it means to be part of an educational community that promises to prepare its students to

87 Kristin E. Heyer, "Community-Based Learning," in Education for Faith and Justice: Catholic Higher Education Today, ed. Thomas P. Rausch (Collegeville, MN: Liturgical Press, 2010), 103-110.

88 Stephen J. Pope, "Immersion Trips," in Rausch, 127-42. 


\section{Orientations of new faculty and staff have to include explicit introductions to what it means to be part of an educational community that promises to prepare its students to be transformational leaders.}

be transformational leaders, i.e., to be part of structural change to make the world a better place for all, especially those most in need, such as the extremely poor. Thus it is essential to provide educational opportunities to familiarize faculty and staff with principles of CST. In its Mission Statement, St. Edward's University in Austin, Texas, promises to help students to "recognize their responsibility to the world community." That university also has a nationally recognized multifaceted program to educate its student affairs staff on how to help students develop their moral reasoning skills, understand the principles of CST, and live out the global spirit of its founders, the Congregation of Holy Cross. ${ }^{89}$

At St. Catherine University, a stipended, week-long, small-group summer workshop for faculty and staff provides information on the Catholic intellectual tradition and on CST, access to extensive resources, and opportunity for multiple discussions in an ambiance conducive to new relationships among persons of various backgrounds, disciplines, and areas of responsibility. During the week, each person or department prepares a project of some kind for incorporating principles of CST and/or Catholic intellectual tradition in their ongoing work, and then shares that project or plans for it with the group. Evaluations by participants record personal and professional transformation from this experience.

Faculty scholarship is another significant way to foster contributions to the development of perspectives shaped by principles of Catholic social teaching. The kind of questions faculty members are investigating clearly influence the design of their courses. Since I992, the annual Collegium: A Colloquy on Faith and Intellectual Life has seeded research questions and opportunities for faculty from Catholic universities all over the nation. In recent years, fellowships for graduate students preparing to be college educators have been added. Now many more examples of permeation of faith-based principles in the educational process are available in the increasing written testimonies of work being carried on recently at various Catholic colleges and universities..$^{\circ}$

Education in social responsibility is also an important dimension of the discernment of vocation, one of the key developmental tasks of traditional-aged college students. In

89 St. Edward's University, "Mission Statement," www.stedwards.edu.

90 See, for example: Karen E. Eifler and Thomas M. Landy, eds., Becoming Beholders: Cultivating Sacramental Imagination and Actions in College Classrooms (Collegeville, MN: Liturgical Press, 2014); Meghan J. Clark, The Vision of Solidarity and the Praxis of Human Rights (Minneapolis, MN: Fortress Press, 2014); Susan Crawford Sullivan and Ron Pagnucco, eds., A Vision of Justice: Engaging Catholic Social Teaching on the College Campus (Collegeville, MN: Liturgical Press, 2014). 
an era when financial security and monetary goals are given undue prominence, the importance of discerning one's life purpose needs particular emphasis. Pope Francis has called business "a noble vocation"91 and politics "a lofty vocation." ${ }^{2}$ Education in the principles of Catholic social teaching about economic justice and the responsibilities of governments for the common good can inspire vocational choices. Consideration of alternative economic arrangements and policies (as envisioned in CST) can motivate the kind of institutional innovation so urgently needed to bring a more equitable world for the future. To help create these new institutions will be the task of the generations we are educating. They need to understand that current social, economic, and political institutions were made by human beings, and we humans can change them.

Evoking a spirit of hope can be another fruit of emphasizing the values of CST throughout education at our universities. The prevalence of cynicism feeds a sense of personal and social impotence and obstructs the political will for change. Pope Francis has called for "no to sterile pessimism." 93 Helping students to understand what is, to see the potential for alternatives, and to celebrate the "success stories" of people who have made a difference can motivate them to act for justice. It is essential that educators help students not only to think critically about current realities but also to recognize those largely unknown events that are seeding change.

International relations scholar Richard Falk wrote about "rooted utopianism,"94 reminding us that acting for systemic change is not "pie in the sky" because there are evidences that change is underway all around us. For example, teaching about diverse forms of social entrepreneurship, microfinance, fair trade movements, benefit corporations, and corporate social responsibility can counter cynicism, stimulate innovation, and evoke hope.

A sign of belief in the possibility of change is the slogan of the World Social Forum about the poor of the global South: "Another World is Possible." World progress, accomplished through focused collaborative action on the Millennium Development Goals, described briefly in the first part of this paper, evidences what can be done. "Mindful markets" are possible if enough people work to promote attitudes and enact market-shaping public policies rooted in the principles of CST. 95

In sum, this paper has argued for greater focus on the principles of economic justice laid out in CST in order to educate more graduates from our universities who will help develop the political will necessary to eradicate extreme poverty-the obscenity of denying the basic necessities of life to the poorest of our brothers and sisters in this world of great abundance.

91 EG 203.

92 EG 205.

93 EC 84-86.

94 Richard Falk, Predatory Globalization: A Critique (Cambridge: Polity Press, 1999), 59.

95 David C. Korten, The Post-Corporate World: Life After Capitalism (San Francisco: Berret-Koehler Publishers and Kumarian Press, 1999), 41. 
This challenge may seem overwhelming, since social change is complex and often long in coming. But as educators we can take heart from the words of the great anthropologist Margaret Mead, who summarized her seminal research in an oft-quoted adage:

Never doubt that a small group of thoughtful committed citizens can change the world; indeed it's the only thing that ever has. 


\section{Bibliography}

Banerjee, Abhijit and Esther Duflo. Poor Economics: A Radical Rethinking of the Way to Fight Global Poverty. Philadelphia: Affairs, 20 II.

Baum, Gregory. Compassion \& Solidarity: The Church for Others. New York: Paulist Press, I990.

Brackley, Dean. "Higher Standards.” America, February 6, 2006, 9-13.

Clark, Meghan I. The Vision of Solidarity and the Praxis of Human Rights. Minneapolis: Fortress Press, 20I4.

Coleman, John A. “The Future of Catholic Social Thought.” Modern Catholic Social Teaching: Commentaries and Interpretations, edited by Kenneth Himes, 522-44. Washington: Georgetown University Press, 2005.

-----. "Neither Liberal nor Socialist." One Hundred Years of Catholic Social Thought: Celebration and Challenge. John A. Coleman, ed. Maryknoll: Orbis Books, I99I, 25-42. Coleman, John A. and William F. Ryan, eds. Globalization and Catholic Social Thought: Present Crisis, Future Hope. Maryknoll: Orbis Books, 2005.

Collier, Paul. The Bottom Billion: Why the Poorest Countries Are Failing and What Can Be Done About It. New York: Oxford, 2007.

Curran, Charles E. Catholic Social Teaching 1891-Present: A Historical, Theological, and Ethical Analysis. Washington: Georgetown University Press, 2002.

Dorr, Donal. Option for the Poor: A Hundred Years of Catholic Social Teaching. Revised ed. Maryknoll: Orbis Books, I992.

Eifler, Karen E. and Thomas M. Landy, eds. Becoming Beholders: Cultivating Sacramental Imagination and Actions in College Classrooms. Collegeville: Liturgical Press, 2014.

Falk, Richard. Predatory Globalization: A Critique. Cambridge: Polity Press, I999.

Finn, Daniel K. Christian Economic Ethics: History and Implications. Minneapolis: Fortress Press, 20I3.

Finn, Daniel K., ed. The True Wealth of Nations: Catholic Social Thought and Economic Life. New York: Oxford University Press, 20Iо.

Friere, Paulo. Pedagogy of the Oppressed. New York: Seabury Press, I970.

Gaillardetz, Richard. "The Ecclesiological Foundations of Modern Catholic Social Teaching." Modern Catholic Social Teaching: Commentaries and Interpretations, edited by Kenneth Himes. Washington: Georgetown University Press, 2005, 72-98.

Haughey, John C. The Holy Use of Money: Personal Finances in Light of Christian Faith. Garden City: Doubleday \& Company, I986.

-----. Where Is Knowing Going? The Horizons of the Knowing Subject. Washington: Georgetown University Press, 2009.

Heibroner, Robert L. The Making of Economic Society. Englewood Cliffs: Prentice-Hall, Inc., I962.

Heyer, Kristin E. "Community-Based Learning.” Education for Justice: Catholic Higher Education Today, edited by Thomas P. Rausch. Collegeville: Liturgical Press, 20ıо, IO3-IO. 
Hofbauer, Rita, Dorothy Kinsella, and Amata Miller. Making Social Analysis Useful. Washington: Leadership Conference of Women Religious, I985.

Holland, Joe and Peter Henriot. Social Analysis: Linking Faith and Justice. Revised and enlarged ed. Maryknoll: Orbis Books, i983.

Hollenbach, David. Claims in Conflict: Retrieving and Renewing the Catholic Human Rights Tradition. New York: Paulist Press, I979.

-----. "Economic Justice and the New Challenges of Globalization." The Almighty and the Dollar: Reflections on 'Economic Justice For All', edited by Mark J. Allman. Winona: Anselm Academic, 2012, 98-II3.

Himes, Kenneth. "Introduction." Modern Catholic Social Teaching: Commentaries and Interpretations, edited by Kenneth Himes. Washington: Georgetown University Press, 2005, I-6.

International Labour Organization, World Commission on the Social Dimensions of Globalization. A Fair Globalization: Creating Opportunities for All. Final Report. February 24, 2004.

Kammer, Fred. Doing Faithjustice: An Introduction to Catholic Social Thought. Revised ed. New York: Paulist Press, 2004.

Kavanaugh, John F. Following Christ in a Consumer Society: The Spirituality of Cultural Resistance. 25th anniversary ed. Maryknoll: Orbis Books, 2006.

Korten, David C. The Post Corporate World: Life After Capitalism. San Francisco: BerrettKoehler Publishers and Kumarian Press, I999.

Massaro, Thomas. Living Justice: Catholic Social Teaching in Action. 2d Classroom ed. Lanham: Rowman \& Littlefield Publishers, 20 I2.

McDonagh, Francis. Dom Helder Camara: Essential Writings. Modern Spiritual Masters Series. Maryknoll: Orbis Books, 2009.

McGovern, Arthur. Marxism: An American Christian Perspective. Maryknoll: Orbis Books, I980.

Miller, Amata. “The Centennial Encyclical_Centesimus Annus.” Theology \& Public Policy, 3, no. 2 (Fall, I99I): I6-2I.

-----. "Once a Sin, Now Good Stewardship." Rome Has Spoken; A Guide to Forgotten Papal Statements, and How They Have Changed Through the Centuries. Edited by Maureen Fiedler and Linda Rabben. New York: Crossroad Publishing Company, I998, 202-06. -----. "Catholic Social Teaching-What Might Have Been if Women Were Not Invisible in a Patriarchal Society.” Journal for Peace a Justice Studies 3, no.2 (I99I), 5I-70.

Novak, Michael. The Catholic Ethic and the Spirit of Capitalism. New York: Free Press, I993.

O'Brien, David. “The United States' Historical Engagement with Catholic Social Teaching." Susan Crawford Sullivan and Ron Pagnuccio, eds. A Vision of Justice: Engaging Catholic Social Teaching on the College Campus. Collegeville: Liturgical Press, 20I4, I-I6.

O’Brien, David J. "A Century of Catholic Social Teaching: Contexts and Comments." 
David J. O'Brien, ed. One Hundred Years of Catholic Social Teaching: Celebration and Challenges." Maryknoll: Orbis Books, I991, I3-24.

O'Brien, David J. and Thomas A. Shannon, eds. Catholic Social Thought: The Documentary Heritage. Expanded ed. Maryknoll: Orbis Books, 20 Iо.

Ong, Walter. "Yeast." America, April 7, I990, 347-51.

Picketty, Thomas. Capital in the Twenty-first Century. Cambridge: Harvard University Press, 20I4.

Pontifical Council for Justice and Peace. Compendium of the Social Doctrine of the Church. Washington: United States Conference of Catholic Bishops, 2005.

Pope, Stephen J. “Immersion Trips.” Thomas P. Rausch, ed. Education for Justice: Catholic Higher Education Today. Collegeville: Liturgical Press, 2010, I27-I42.

Porter, Eduardo. “In New Tack, I.M.F. Aims at Income Inequality.” New York Times, April 8, 2014 , sec. B.

Rodrik, Dani. The Globalization Paradox: Democracy and the Future of the World Economy. New York: W.W. Norton, 2011.

Sachs, Jeffrey D. Common Wealth: Economics for a Crowded Planet. New York: Penguin, 2008.

-----. The End of Poverty: Economic Possibilities for Our Times. New York: Penguin, 2005.

School of Social Work. Social Work for Social Justice: Ten Principles. St. Paul: St. Catherine University \& University of St. Thomas, 2006.

Schubeck, Thomas I. Love That Does Justice. Maryknoll: Orbis Books, 2007.

Shuck, Michael. “Early Modern Roman Catholic Social Thought, I740-I89o.” Kenneth Himes, ed. Modern Catholic Social Teaching: Commentaries and Interpretations. Washington: Georgetown University Press, 2005, 99-124.

Sider, Ronald J. Rich Christians in an Age of Hunger: A Biblical Study. New York: Paulist Press, I977.

St. Edward's University. "Mission Statement.” www.stedwards.edu.

Stebbins, J. Michael. “The 'Real World' of Business.” John C. Haughey, ed. In Search of the Whole: Twelve Essays on Faith and Academic Life. Washington: Georgetown University Press, 2011, 85-96.

Stiglitz, Joseph E. The Price of Inequality: How Today's Divided Society Endangers Our Future. New York: W.W. Norton, 2012.

Sullivan, Susan Crawford and Ron Pagnuccio, eds. A Vision of Justice: Engaging Catholic Social Teaching on the College Campus. Collegeville: Liturgical Press, 20I4.

United Nations. The Millennium Development Goals Report 2014. New York: United Nations, 20I4.

United Nations Development Programme. Human Development Report 2014: Sustaining Human Progress: Reducing Vulnerabilities and Building Resilience. New York: United Nations, 20I4.

Weigert, Kathleen Maas. "Living the Catholic Social Tradition: Introduction and Overview.” Kathleen Maas Weigert and Alexia K. Kelly, eds. Living Catholic Social 
Tradition: Cases and Commentary, Lanham: Rowman \& Littlefield Publishers, 2005, 3-I4.

Wilkinson, Richard and Kate Pickett. The Spirit Level: Why More Equal Societies Almost Always Do Better. London: Penguin, 2009.

World Bank, “Measuring Poverty Overview," www.worldbank.org/en/topic/ measuringpoverty/overview\#I, accessed 8/I4/I4.

\section{Abbreviations}

CA Centesimus Annus (On the Hundredth Anniversary of Rerum Novarum), Pope John Paul II, I99I

CV Caritas in Veritate (Charity in Truth), Pope Benedict XVI, 2009

DCE Deus Caritas Est (God Is Love), Pope Benedict XVI, 2005

EG Evangelii Gaudium (Joy of the Gospel), Pope Francis, 20I3

EJA Economic Justice for All: Pastoral Letter on Catholic Social Teaching and the U.S. Economy. National Conference of Catholic Bishops, I986 (at www.usccb.org/ upload/economic_justice_for_all.pdf)

GS Gaudium et Spes (Pastoral Constitution on the Church in the Modern World), Vatican II, I965

JM Justitia in Mundo (Justice in the World), Synod of Bishops, I97I (at www.shc.edu/ theolibrary/resources/synodjw.htm)

LE Laborem Exercens (On Human Work), Pope John Paul II, I98I

MM Mater et Magistra (Christianity and Social Progress), Pope John XXIII, I96I

OA Octogesima Adveniens (A Call to Action on the Eightieth Anniversary of Rerum Novarum), Pope Paul VI, I97I

RH Redemptor Hominis (On the Redeemer of Man), Pope John Paul II, I979

RN Rerum Novarum (On the Condition of Labor), Pope Leo XIII, I89I

PP Populorum Progressio (On the Development of Peoples), Pope Paul VI, I967

PT Pacem in Terris (Peace on Earth), Pope John XXIII, I963

QA Quadragesimo Anno (After Forty Years), Pope Pius XI, I93I

SRS Sollicitudo Rei Socialis (On Social Concern), Pope John Paul II, I987

All of the above are available at www.vatican.va except as noted. 